\title{
Powojenna mediewistyka polska wobec dziedzictwa dziewiętnastowiecznej myśli historycznej
}

W naukach historycznych zaobserwować można splecenie dwu, rozdzielonych przez Thomasa Kuhna, zasad naukowych — zasady kumulatywności oraz rewolucji naukowej. Mamy oto bowiem nierozerwalnie związane ze sobą dwa zjawiska. Z jednej strony to, co nazywamy rozwojem nauk historycznych, a co w podejściu pozytywistycznym można rozumieć jako stały przyrost wiedzy na temat przeszłości, lepszego jej rozumienia, wyjaśniania i publikacji źródeł. Z drugiej zaś strony każde pokolenie badaczy tworzy swój obraz przeszłości, niekoniecznie rewolucyjnie odmienny od zbudowanego przez poprzedników, ale w jakimś sensie inny od dotychczasowego. Dla większości historyków obowiązkowa jest refleksja nad swym miejscem w badaniach historycznych zawarta w dokonywanym w prawie każdej pracy podsumowaniu stanu dotychczasowej wiedzy i formułowanych na zakończenie badań postulatach. Często jednak rozważania takie sprowadzają się do prostego wyliczenia autorów, tekstów i ustaleń poprzedników. Rzadko kiedy natomiast podejmuje się ogólniejszą refleksję nad funkcjonującym w naukach historycznych paradygmatem, czyli zbiorem przekonań funkcjonujących w środowisku naukowym oraz przyjętych w drodze konsensusu modelach i praktykach badawczych ${ }^{1}$.

${ }^{1}$ Zdaję sobie sprawę z niepełnej przystawalności koncepcji Thomasa Kunna (The Structure of Scientific Revolutions. Chicago 1962) do nauk historycznych. Już Jerzy TopoLSKI twierdził, że ta teoria nie ma w nich zastosowania. Por. TenżE: Główne tendencje rozwojowe historiografii XIX i XX wieku. Kw. Hist. 1983, T. 90, s. 840 n.; TenżE: Jak się pisze i rozumie historię. Tajemnice narracji historycznej. Poznań 2008, s. 223. Kuhn dowodzi, że nauka nie jest jednostajnym, kumulatywnym pozyskiwaniem wiedzy. Tymczasem w naukach historycz- 
Zadaniem niniejszego szkicu jest namysł nad obecnością w polskiej mediewistyce historycznej czasów powojennych (po 1945 roku) przekonań i wizji przeszłości wypracowanych jeszcze w XIX stuleciu, czyli u progu tworzenia się nowoczesnej, krytycznej historiografii. Z praktycznych względów rzecz dotyczyć będzie tylko mediewistyki historycznej, bez odwoływania się do innych nauk zajmujących się średniowieczem. $Z$ obowiązku uzasadniania i definiowania mediewistyki historycznej zwalnia mnie choćby obecna już od kilkunastu lat w nauce praktyka działań Stałego Komitetu Mediewistów Polskich. Od niedawna możemy odwoływać się do konkretnych rozpraw dotyczących dziejów badań mediewistycznych ${ }^{2}$. W niniejszym artykule oparto się rzecz jasna na wybranych pracach, zestawiając przykłady pochodzące z syntez, monografii i tekstów popularnonaukowych, będące egzemplifikacją określonych paradygmatów.

Refleksja nad obecnością w paradygmacie współczesnej mediewistyki przekonań wypracowanych w XIX stuleciu nie jest zbyt często podejmowana. Wynika to z pewnej niechęci badaczy do sięgania nie tyle do źródeł historycznych sensu stricto, ile do „źródeł” wiedzy historycznej. Starsza, pochodząca z XIX wieku literatura należy, w przekonaniu niektórych historyków, do swoistego „lamusa nauki”, a odwoływanie się do niej wydaje się niepotrzebne. Jeżeli dziś często teksty historyczne $\mathrm{z}$ lat powojennych uznawane są za przestarzałe, cóż dopiero mówić o literaturze sprzed dwu stuleci. Niektóre prace sprzed lat 1905-1910 traktuje się jako klasyczne teksty historiograficzne, nie sięgając specjalnie w głąb XIX wieku.

Czy słusznie? Czy rzeczywiście możemy zapomnieć o początkach nowożytnej historiografii, zapomnieć o wypracowanych w tamtym czasie przekonaniach o przeszłości? Można zawsze powiedzieć, że jesteśmy bogatsi w nowe, nieznane wówczas teksty źródłowe, dysponujemy lepszymi (a przynajmniej tak nam się wydaje) narzędziami badawczymi, dzielą nas od tamtej nauki setki czy tysiące opracowań i ustaleń. Czy jednak nie jest tak, że wiele wtedy sformułowanych przekonań o średniowieczu zaznacza swą obecność w naszej tzw. wiedzy pozaźródłowej?

Dorobku dziewiętnastowiecznej historiografii polskiej w aspekcie poznania średniowiecza nie sposób przecenić. Jako pierwszy wskazać należy ogromny dorobek edytorski. Większość tekstów narracyjnych dotyczących polskiego średniowiecza wówczas ukazała się drukiem. To wydanie sześciu tomów „Pomników Dziejowych Polski” („Monumenta Poloniae Historica”), które ukazały się w latach 1864-1893 we Lwowie. Wzorowane na niemieckiej „Monumenta

nych kumulatywność jest zjawiskiem naturalnym. Pomimo to Kuhnowska teoria paradygmatu jest dobrym narzędziem przy refleksji natury historiograficznej.

${ }^{2}$ Por. Mediewistyka polska w XX wieku (wybrane problemy). Red. S. KwiatKowsKI. Wrocław 2008; S. KwistKowsKi: Polska mediewistyka historyczna w czasach maszynopisu. O wymuszonej modernizacji i okolicznościach jej przemijania. Poznań 2010. 
Germaniae Historica" pozostają do dziś podstawową i kontynuowaną edycją polskich tekstów narracyjnych. Dowodem wartości tego wydania jest jego reprint z lat 60. XX wieku oraz statystyki korzystających z wersji digitalnych zamieszczonych w Kujawsko-Pomorskiej Bibliotece Cyfrowej ${ }^{3}$. Dzięki staraniom i pracy Aleksandra Przeździeckiego opublikowano w latach 1863-1864 Liber beneficiorum Jana Długosza, a w latach 1867-1870 Dzieje polskie w ksiegach dwunastu w przekładzie Karola Mecherzyńskiego - pierwszą kompletną, polską edycję najważniejszego dzieła Długosza. Hrabia Przeździecki w 1862 roku wydał Kronike Wincentego Kadtubka. Z prac Długosza tylko niektóre doczekały się współczesnych edycji. W przypadku innych jego dzieł korzystamy z dorobku wydawców dziewiętnastowiecznych. W tym stuleciu podjęto także prace edytorskie nad dokumentami polskimi. Edycje dyplomatyczne dla całej Polski podjęto jako Codex diplomaticus Poloniae. Zaczęto również wydawać kodeksy regionalne - dla Wielkopolski, Małopolski, Mazowsza, Kujaw, Śląska, Pomorza, Prus Wschodnich. Edycje te opracowywali historycy polscy i niemieccy, a wiele z nich posiada współczesne kontynuacje. Biorąc pod uwagę ówczesne możliwości komunikacyjne, niewielkie wsparcie techniczne (pióro i atrament zamiast komputerów), możemy jedynie pochylić głowę przed tą tytaniczną pracą.

Od końca XVIII wieku obserwujemy pojawianie się syntez dziejów polskich. Poczynając od Adama Naruszewicza, przez prace powstałe na skutek działań Towarzystwa Przyjaciół Nauk, liczba pozycji dotyczących całości bądź tylko fragmentów historii Polski rośnie ${ }^{4}$. Średniowiecze z perspektywy ówczesnych historyków zajmowało miejsce szczególne - to początki oraz pierwsze wieki państwa i narodu. W większości podejmowanych prób wyjaśnienia zawiłości dziejów narodowych musiano sięgać do przysłowiowych Adama i Ewy, czyli w tym przypadku do średniowiecza. Wartość faktograficzna tamtejszych opracowań nie jest z naszej perspektywy już znacząca. Wiemy więcej i lepiej. Powstałe jednak wówczas wizje przeszłości obecne są w naszej świadomości czy podświadomości po dziś dzień. O wartości i wadze ówczesnych ujęć syntetycznych świadczą ukazujące się regularnie wznowienia czy reprinty tamtych prac. Wymienić można tu niedawno wszak wydane dzieła Wacława Aleksandra Maciejowskiego, Pawła Szafarzyka czy Richarda Roeppela5.

${ }^{3}$ Liczba wyświetleń na dzień 8 stycznia 2020 r.: tomu 1 (dodany 5 maja 2006) - 37 760, tomu 2 (dodany 29 maja 2006) - 47 147, tomu 3 (dodany 30 maja 2006) - 19 037, tomu 4 (dodany 29 maja 2006) - 19 883, tomu 5 (dodany 1 czerwca 2006) - 22 146, tomu 6 (dodany 5 września 2006) - 18 300. Dane zawarte w stale aktualizowanych informacjach Kujawsko-Pomorskiej Biblioteki Cyfrowej.

${ }^{4}$ Zmiany w metodologii tworzenia narodowych syntez omówiła M. WierzBicka: Dawne syntezy dziejów Polski. Rozwój i przemiany koncepcji metodologicznych. Wrocław-Warszawa-Kraków—Gdańsk 1974.

${ }_{5}^{5}$ Współczesnej edycji tych tekstów podjęło się niedawno Poznańskie Towarzystwo Przyjaciół Nauk: P.J. SzafarzyK: Stowiańskie starożytności. Poznań 2003; W.A. MaCieJowski: 
W niniejszym szkicu nie chcę tworzyć peanu na cześć historiografii XIX wieku. O wiele ważniejsze jest dostrzeżenie, w których ze stosowanych współcześnie elementów narracji historycznej opieramy się na ówczesnych pomysłach i sposobach postrzegania świata. Podstawowym elementem paradygmatu historiografii dziewiętnastego stulecia jest wizja historii narodowej. Niewielu z niegdysiejszych historyków uwolniło się od tego jarzma. Dla wielu stanowiło ono istotną motywację do zajmowania się przeszłością. Nigdy wszak historia nie stała się nauką wolną od polityki. Marek Cetwiński z perspektywy badań nad śląską mediewistyką określił to mianem paradygmatu Stenzla ${ }^{6}$. Odwołał się do postaci i prac wrocławskiego historyka Gustawa Adolfa Stenzla, który historię postrzegał jako przejaw postępu idei wolności, prawo gwarantujące wolność powinno zaś odpowiadać historycznie ukształtowanym cechom danej społeczności. Ponieważ według tego badacza owa wolność oraz prawo wiązały się na Wschodzie z szerzeniem się niemieckiej kultury, jego wizja dziejów stawała się wizją narodową. Podobnie uwikłanie mediewistyki w ideologię narodową postrzegał zmarły niedawno Dušan Třeštík. Zastanawiając się nad problemem ekspansji karolińskiej nad środkowym Dunajem w IX wieku, napisał: „Jeżeli jednak, opisując wiek IX, zrezygnujemy z pojęcia »naród« (tożsamego ze współczesnym narodem) jako podmiotu historii, legnie w gruzach obraz zbiorowej tożsamości, tworzony właśnie za pomocą tego pojęcia przez dwa ostatnie stulecia. Należy więc zadać pytanie, kto wówczas rzeczywiście tworzył historię, jeśli nie byli to »Niemcy«, »Słowacy« ani też współcześni »Czesi« czy »Chorwaci«. Innymi słowy pojawi się problem, czyją historię mamy właściwie opowiadać"8.

Dochodzimy w tym miejscu do jednego z pierwszych elementów dziewiętnastowiecznego paradygmatu historiografii, obecnego wciąż we współczesnej narracji naukowej i popularnonaukowej, czyli identyfikacji z przeszłością, połączonej z poglądem o odwiecznym istnieniu narodu. Według tego przekonania naród istnieje niemal od zawsze, w węższym czy w szerszym rozumieniu, a obecne pokolenia dziedziczą pewne cechy przodków, które zwie się charakterem narodowym. Pogląd ten występuje niemal w całej historiografii dziewiętnastego stulecia. Zgodnie z nim, z uwagi na fakt dziedziczenia cech poszczególnych pokoleń, następuje identyfikacja z przeszłością. To nasza przeszłość - nasi przodkowie to niemal my, tylko kiedyś. Na gruncie polskiej historiografii, ale nie tylko, mamy do czynienia z identyfikacją natury

Pierwotne dzieje Polski i Litwy. Poznań 2005; W. BogusŁawski: Dzieje Stowiańszczyzny pótnocno-zachodniej. Poznań 2005; R. Roepell: Dzieje Polski do XIV stulecia. Poznań 2005.

${ }^{6}$ M. CETwiŃski: Historia i polityka. Teoria i praktyka mediewistyki na przykładzie badań dziejów Ślaska. Kraków 2008, s. 53-121.

7 Tamże, s. 55.

${ }^{8}$ D. TřešTík: Powstanie Wielkich Moraw. Morawianie, Czesi i Europa Środkowa w latach 791-871. Przeł. E.H. KaczmarsKa. Warszawa 2009, s. 15. 
podwójnej: „my — Polacy” oraz „my — Słowianie”. Najlepszą ilustracją tego przekonania jest propagandowe hasło z okresu PRL-u dotyczące Ziem Odzyskanych: „Byliśmy, jesteśmy, będziemy”. Identyfikacja z przeszłością widoczna jest w wielu pracach naukowych i popularnonaukowych, nie mówiąc już o literaturze pięknej i popularyzatorskiej. Przekonania o naszej historii, naszej przeszłości czy naszych dziejach są dość powszechne. Jeżeli tak, jak pisał Cyprian Kamil Norwid:

Przeszłość - to jest dziś,

tylko cokolwiek dalej.

Nie jakieś tam coś, gdzieś,

gdzie nigdy ludzie nie bywali ${ }^{9}$.

— identyfikacja z przeszłością nas współczesnych przy tworzeniu historii narodowej staje się kwestią w pełni zrozumiałą. Dziewiętnastowieczny historyzm w Polsce nabrał szczególnego znaczenia, gdyż przeszłość stawała się punktem wyjścia do rozważań o przyczynach narodowej katastrofy, jaką były rozbiory ${ }^{10}$. Dla historiografii powojennej, przed którą stały nowe zadania polityczne, historyzm narodowy i związana z nim identyfikacja z przeszłością były wygodnym oraz społecznie oczekiwanym narzędziem nie tyle badawczym, ile przede wszystkim narracyjnym ${ }^{11}$. W przywołanym propagandowym haśle: „Byliśmy, jesteśmy, będziemy”, historykom przyszło dowodzić członu pierwszego — „byliśmy". Szczególna rola przypadła tu mediewistom, gdyż związki państwowe Śląska i Pomorza Zachodniego istniały tylko w tej epoce. Ta identyfikująca się z przeszłością narracja miała wymiar narodowy — polski, czasem szerszy — słowiański. Stąd też wynikała jej jednostronność. W przypadku Śląska można to zauważyć w pracy Kazimierza Popiołka, który niewielką część swej syntezy dziejów Śląska poświęcił średniowieczu, wskazując przede wszystkim polskie aspekty losów tego regionu ${ }^{12}$. Większość jego rozprawy odnosi się do Górnego Śląska, gdyż tam przetrwał ,żywioł polski”. Identyfikacja etniczna w opisie dziejów narodowych oraz $\mathrm{w}$ badaniach była tu obowiązującym powszechnie elementem paradygmatu badawczego. Przy tworzeniu monografii miejscowości wskazywano zwykle na polskie czy słowiańskie jej początki. Przykładowo,

9 C.K. Norwid: Przeszłość. W: TenżE: Poezje. Poznań 1986, s. 523.

${ }^{10}$ P. Boroń: Stowianie - my i nasi przodkowie. Etyczne aspekty poszukiwania pradawnej chwaty ludów slowiańskich $w$ pracach historyków polskich I połowy XIX wieku. W: Narracje - (auto)biografia - etyka. Red. L. Koczanowicz, R. NAhirny, R. WŁodarczyK. Wrocław 2005, s. 268.

${ }^{11} \mathrm{~W}$ innym kontekście podobną tendencję w historiografii polskiej ukazał Wojciech IwAŃCZAK, omawiając problem postrzegania $\mathrm{w}$ XX wieku procesów związanych z kolonizacją niemiecką. Por. TenżE: Między Europa i Azją. Sąsiedzi Polski w świetle mediewistyki XX wieku. W: Mediewistyka polska w XX wieku..., s. 37.

${ }^{12}$ K. PopioleK: Historia Śląska od pradziejów do 1945 roku. Katowice 1984. 
w opisie miasta, które lokowano na prawie niemieckim na surowym korzeniu, musiały pojawić się informacje o wcześniejszych, słowiańskich początkach (np. Gliwice). Nawet przy badaniach archeologicznych niezbyt pasujące do słowiańskich początków artefakty zostawały albo przemilczane, albo usuwane jako nowożytne wtręty (np. Szczecin).

Poszukiwanie elementów polskich w przeszłości jako podstaw identyfikacji narodowej dość łatwe było na terenie Śląska czy Pomorza Gdańskiego. Zdecydowanie gorzej przedstawiało się to na Pomorzu Zachodnim, tam jednak albo wskazywano na słowiańskie więzi, albo nie wspominano o sporej rozbieżności między losami tego regionu a historią narodową. Jednocześnie wyjątkowo mocno podkreślane były te wydarzenia, w których dzieje Pomorza Zachodniego splatały się z historią Polski. Stąd właśnie wynikła „kariera” Bogusława X w historiografii polskiej. Największe trudności dla historyków próbujących udowadniać część hasła: „byliśmy”, czekały na terenie Polski północno-wschodniej. I o ile związki Warmii z historią narodową od końca średniowiecza są niepodważalne, o tyle w przypadku terenów dawnych tzw. Prus Książęcych sprawa wygląda nieciekawie. Może też jest to jeden z powodów, dla których dość późno powstały syntezy dziejów tego regionu ${ }^{13}$. Tutaj szczególnie widoczny jest dylemat przedstawiony przez Třeštíka - czyją historię będziemy pisać? Jeżeli jednym z elementów paradygmatu badawczego jest wynikająca $\mathrm{z}$ uwarunkowań historii narodowej identyfikacja $\mathrm{z}$ przeszłością, zagadnienie dotyczące tego, czy mówimy o naszej przeszłości, jest wyjątkowo istotne.

Znamienne dla tego rodzaju postawy badawczej jest zakończenie pracy Piotra Bogdanowicza o przynależności politycznej Śląska w X wieku. Zaprezentował on tam postawę pełnej identyfikacji z przeszłością, a przekonanie o znaczeniu pewnych faktów historycznych dla świadomości narodowej zostało wyartykułowane dobitnie w próbie oceny dziejów Czech:

Przeprowadziwszy, jak sądzimy, dowód niemożności istnienia panowania czeskiego na Śląsku i w południowych ziemiach polskich w X w., przyczyniliśmy się do zburzenia legendy o „złotym wieku” dziejów czeskich za panowania Bolesława I i Bolesława II. Burzenie mitów w nauce jest zawsze oddaną przysługą, gdyż zbliża do jedynej rzeczywistej wartości w nauce, jaką jest prawda. Pobratymczy naród czeski może spokojnie zrezygnować z wszelkich mitów w swojej historiografii, zwłaszcza że ma na swoim średniowiecznym koncie dziejowym pozycje niewątpliwie imponujące i historycznie całkowicie pewne, choćby fakt, że właśnie Przemyślida nosił koronę Piastów (1300 r.), że na głowach królów czeskich spoczywał przez kilka pokoleń diadem cesarzy „rzymskich”, a także

${ }_{13}$ Dzieje Warmii i Mazur w zarysie. T. 1. Red. J. Sikorski, S. Szostakowski. Warszawa 1981; T. 2. Red. T. Filipkowski [et al.]. Warszawa 1983; S. Achremczyк: Historia Warmii i Mazur: od pradziejów do 1945 roku. Olsztyn 1992. 
i korona węgierska, a przede wszystkim, że właśnie w Pradze powstał pierwszy w Europie środkowej, przede wszystkim przed wszystkimi niemieckimi i polskim, uniwersytet - instytucja, która przetrwała dotąd i zapewne wieki jeszcze przetrwa. A w stosunku do Polski, czy nie jest dostatecznie imponująca okoliczność, że właśnie Przemyślidzi wprowadzili państwo Piastów w świat kultury chrześcijańskiej ${ }^{14}$

Jednym z ciekawszych określeń zastosowanych w tym wywodzie jest swoista metafora o ,średniowiecznym koncie dziejowym”. Czym ono miałoby być, oczywiście nie wiemy, ale mamy wrażenie, że zasługi, ale też pewnie grzechy przodków odkładają się na owym ,koncie dziejowym”, a historyk występuje w roli księgowego czy bankiera opisującego stan owego „konta”. W tym postrzeganiu przeszłości badacz zakłada istnienie ciągłości dziejów, w której pokolenia współczesne dziedziczą osiągnięcia i wielkość swych poprzedników. To chyba właściwa ilustracja paradygmatu Stenzla połączonego z postawą narodowej identyfikacji z przeszłością.

Drugi z elementów odziedziczonego po dziewiętnastowiecznej historiografii paradygmatu to przekonanie o istnieniu państwa jako bytu niezmiennego, współistniejącego z narodem. Historia narodu, według tej koncepcji, jest nierozerwalnie związana z historią państwa. Dylemat, jak traktować dzieje narodowe, widać w najnowszej syntezie dziejów średniowiecznej Polski — pracy Stanisława Szczura. Zastanawiając się nad cezurami ograniczającymi jego narrację, autor pisze:

W pełni świadomie rozpocząłem wykład historii Polski od połowy X wieku [...] Zdaję sobie sprawę z faktu, że można było przyjąć inną periodyzację i dokonać synchronizacji naszych dziejów z historią powszechną średniowiecza. Wtedy należałoby wykład rozpocząć od V w. i prowadzić go, omawiając pięć stuleci równolegle $\mathrm{z}$ dziejami powszechnymi. Zabieg taki, polegający tak naprawdę na sztucznym wydłużaniu historii państwa, uznałem za bezcelowy. Uważam bowiem, że do X w. nie można mówić o historii Polski, lecz co najwyżej o dziejach terytorium, na którym powstało później państwo [podkr. - P.B.]. Okres bez mała pięciu wieków — od V do X — dotyczy dziejów terytorium między Odrą a Wisłą, na którym powstać miało w przyszłości państwo polskie. Uznałem jednak, że należy pozostawić go archeologom, którzy kompetentnie wyjaśniają wszystkie problemy z nim związane.

Stając przed dylematem, czy przedstawiać dzieje terytorium, czy historię państwa państwa, wybrałem to drugie. Konsekwentnie więc pisałem o historii państwa polskiego w średniowieczu, a nie o średniowiecznych dziejach terytorium, na którym miało powstać. Zrezygnowałem również ze statycznego opisywania dziejów terytorium zajmowanego przez państwo w chwili jego powstania.

${ }^{14}$ P. Bogdanowicz: Przynależność polityczna Ślaska $w X$ wieku. Dzieje problemu oraz próba jego rozwiązania. Wrocław 1968, s. 329. 
Było ono w ogólnych zarysach zbliżone do terenów dzisiejszej Rzeczypospolitej Polskiej, której granice wyznaczone zostały przez wynik drugiej wojny światowej i arbitralne decyzje zwycięskich mocarstw.

Świadomie starałem się zerwać z modelem przedstawiania historii średniowiecznej Polski, który dominował w dotychczasowych ujęciach podręcznikowych. Polegał on, najogólniej mówiąc, na rozpoczynaniu od około V w. i przedstawianiu średniowiecznych dziejów Polski w granicach zajmowanych przez gnieźnieńskie państwo Mieszka I i Bolesława Chrobrego. Rodziło to liczne komplikacje. Przyjmowano bowiem, że do historii państwa polskiego w tej epoce należą na równych prawach dzieje wszystkich terytoriów, które znajdowały się pod zwierzchnictwem Piastów w X i XI w. Stąd na kartach historii Polski przez całe średniowiecze pojawiały się Pomorze Zachodnie czy Śląsk. Nietrudno dostrzec, że szukano w ten sposób historycznego uzasadnienia dla stanu wytworzonego po drugiej wojnie światowej ${ }^{15}$.

Pomimo przedstawionych zastrzeżeń narracja Szczura o dziejach Polski nie zaczyna się od wskazanego przez niego X stulecia, lecz od wieku IX, a podstawą rozważań jest geografia plemienna. Państwo bowiem nie wytworzyło się w próżni, a narracja badacza musi obejmować także naświetlenie dziejów terytorium i ludności, które owe państwo objęło. Poza tym historyk może przecież mówić o pewnych terytoriach jako nienależących do państwa piastowskiego, ale o zamieszkujących tam ludziach milczeć nie wypada, szczególnie gdy badacz posiada rzadkie dla tej epoki teksty źródłowe odnoszące się do tych zagadnień. Pewną próba dostrzeżenia, że naród i państwo nie są zjawiskami odwiecznymi, jest rezygnacja przez Szczura z powszechnie przyjętego w historiografii terminu „podbój wewnętrzny” na określenie sposobu tworzenia państwa piastowskiego. Autor zauważa, że „dla tych, którzy zostali podbici, nie miało to żadnego znaczenia"16. Samo sformułowanie „podbój wewnętrzny” jest przecież elementem przeświadczenia o odwiecznym istnieniu narodu — tworzące się państwo powstaje w warunkach „,wewnątrzpolskich" zmian politycznych. Piastowie dla żadnego z włączanych plemion nie są w świetle tego przeświadczenia najeźdźcami - obcymi. Wszystko dokonuje się „wewnątrz” wyobrażonej narodowej całości. Nasuwa się tu nieodparcie porównanie $\mathrm{z}$ historią biblijną, w której powstanie królestwa izraelskiego jest realizacją boskiego planu, a plemiona izraelskie pochodzą od jednego przodka.

Określenie ,podbój wewnętrzny” jest także przejętym przez historyków XX wieku efektem przemyśleń badaczy poprzedniego stulecia. Błędnie przypisuje się je Gerardowi Labudzie ${ }^{17}$, podczas gdy odnaleźć można je w pracach

15 S. Szczur: Historia Polski. Średniowiecze. Warszawa 2002, s. 15-16.

16 Tamże, s. 17.

17 R. GRZESIK, rec.: Slavnikovci ve středovékém písemnictví úvodní studii..., ed. Rastislav Nový, Praha 1987. Kw. Hist. 1991, T. 98, z. 1, s. 84. 
krakowskiego mediewisty Anatola Lewickiego, a potem Stanisława Zakrzewskiego $^{18}$. Ten błąd może ilustrować ograniczanie się badaczy do niezbyt odległych w czasie tekstów, bez świadomości, że pewne pomysły mogą posiadać zdecydowanie wcześniejszą metrykę. Wcześniej niż u Lewickiego koncepcja i termin „podbój wewnętrzny” pojawiły się w powieści Tomasza Teodora Jeża (Zygmunta Miłkowskiego) w 1863 roku jako wyjaśnienie podziału społecznego w Polsce ${ }^{19}$.

Wyraźna cezura w historii państwa polskiego, jaką stanowi połowa $\mathrm{X}$ wie$\mathrm{ku}$, stwarza pewne trudności przy opisywaniu dziejów narodowych. Jak bowiem o nich pisać, gdy naród nie istnieje. W XIX stuleciu radzono sobie zazwyczaj z tą kwestią, wykorzystując mocno przedłużoną chronologię państwową sporządzoną w początkach XIII wieku przez Wincentego Kadłubka. Historiografia powojenna, opierając się na krytycznych wynikach badań, rozpoczętych w szkole lwowskiej w 1870 roku, napotykała tu istotny problem, wyraźnie wyartykułowany w zacytowanej wcześniej wypowiedzi Stanisława Szczura. Wielu z badaczy radziło sobie, tworząc pojęcie prapolskości. Nie istnieje jeszcze państwo, nie istnieje naród, ale możemy mówić o jego początkach plemionach prapolskich czy kulturze prapolskiej. Józef Kostrzewski napisał znakomitą pracę na temat kultury wczesnośredniowiecznych społeczności w dorzeczu Odry i Wisły, określając ją właśnie mianem kultury prapolskiej ${ }^{20}$. Nie historyk, ale językoznawca Jerzy Nalepa dostrzegł prapolski bastion toponimiczny w Bramie Przemyskiej ${ }^{21}$. O plemionach prapolskich pisali Gerard Labuda, Henryk Łowmiański, Jan Żak czy Bolesław Kumor, żeby wymienić największych. Zazwyczaj utożsamiano zasięg prapolskości z zasięgiem państwa końca panowania Mieszka I. Podobieństwo terytorium państwa Mieszka i granic ustalonych po II wojnie światowej wzmacniało to przekonanie. Prapolskimi miastami nazywano te, które już po II wojnie światowej znalazły się w granicach Polski. Słowo ,prapolski” czy „,prasłowiański” stało się swoistym kluczem narracyjnym w opisie dziejów, ale też weszło do kanonu pojęć

18 A. Lewicki: Zarys historyi Polski i krajów ruskich z nią połączonych. Kraków 1884. W tej pracy Lewicki opisuje jedynie, jak ów podbój miał wyglądać. Sformułowanie „podbój wewnętrzny" pojawiło się dopiero w pośmiertnych wydaniach jego Zarysu historii Polski... Por. S. ZAKrzewski: Okres do schytku XII w. W: Historya polityczna Polski. Cz. 1: Wieki średnie. Oprac. S. Zakrzewski et al. Kraków 1920, s. 22. Por. także K. Śreniowska: Stanisław Zakrzewski: przyczynek do charakterystyki pradów ideologicznych $w$ historiografii polskiej 1893-1936. Łódź 1956.

19 T.T. JEŻ: Historia o pra-pra-pra... wnuku i pra-pra-pra... dziadku. Cz. 1. Wilno 1863, s. 31 .

${ }^{20}$ „Jako kulturę prapolską określamy kulturę Polan, Ślężan, Wiślan, Mazowszan, Kujawian, Pomorzan i innych drobniejszych plemion, z których w zaraniu dziejów utworzył się naród polski” (J. Kostrzewski: Kultura prapolska. Poznań 1949, s. 7).

21 J. Nalepa: Prapolski bastion toponimiczny w Bramie Przemyskiej i Lędzanie. „Onomastica" 1991, T. 36, s. 5-45. 
potocznych. Słyszymy o prapolskim Szczecinie, choć jego związki z Polską w średniowieczu można określić tylko jako epizodyczne ${ }^{22}$.

Dzieje państwa polskiego opisywane $\mathrm{z}$ perspektywy narodowego historyzmu wymagały formułowania odpowiednich ocen i opinii dotyczących poszczególnych osób i wydarzeń. Dość często zaobserwować możemy w narracji historycznej przekonanie o patriotyzmie władców. Dobry władca to taki, który realizuje politykę narodową. Oczywiście kryteria tego, co dobre, a co złe, w tej polityce podlegają zmianom w zależności od sytuacji politycznej w czasach, w których żyje historyk. Henryk Samsonowicz nazywa takie zabiegi narracyjne aktualizacją historii. W końcu, jeśli „Historia est magistra vitae”, wskazać należy te wydarzenia i postacie z dziejów, które najbardziej przydadzą się w procesie dydaktycznym. Zacytujmy tu słowa mistrza:

Szczególną formą aktualizacji występującą i wcześniej, ale w XX wieku przybierającą niekiedy kształty groteskowe, była modernizacja. Postacie z czytanek szkolnych lub podręczników dla mniej zaawansowanych przemawiały jak współczesne, $\mathrm{i}$ to $\mathrm{z}$ wykształceniem uniwersyteckim. Wiek X czy XVII kreowały bohaterów mających świadomość ludzi XX wieku. Powstało zjawisko wyjaśniania teraźniejszości poprzez przeszłość, na pewno generalnie uzasadnione (tak jak spotykane wyjaśnianie przeszłości przez teraźniejszość, przez analizę postaw ludzkich, mechanizmów rynkowych), ale i przeprowadzone bez żadnego uzasadnienia. Mieszko I przemawiał jak zatroskany kaznodzieja, Chrobry snuł plany niemal szersze niż ideolodzy XX-wiecznego panslawizmu, Łokietek odwoływał się do patriotyzmu chłopów, jak gdyby organizował partyzantkę w czasie II wojny światowej, a nie przeciwko Czechom w XIV wieku ${ }^{23}$.

To oczywiście przykłady skrajne, ale przekonanie o nierozerwalnych związkach państwa i narodu nakazuje wielu historykom upatrywać we władcy reprezentanta narodowego właśnie interesu.

Przeciwnicy monarchy stają się $\mathrm{w}$ takim podejściu przeciwnikami narodu. Ich działalność zatem siłą rzeczy musi być oceniana negatywnie. W opiniach historyków tak jak w XIX stuleciu pojawiają się wartościujące epitety. Widzimy to w pracach dotyczących okresu rozbicia dzielnicowego, gdzie znajdujemy słowa: „tendencje odśrodkowe”, „partykularyzm” etc. Dość interesującą ocenę Siemowita III mazowieckiego sformułował Stefan Krzysztof Kuczyński. Siemowit jest dla niego „wybitnym rzecznikiem samodzielności politycz-

22 W. SZafrański: Tadeusz Wieczorowski. „Z Otchłani Wieków” 1971, T. 37, z. 1, s. 4950. W tym nekrologu obok wzmianki o prapolskim Szczecinie pojawia się także określenie „zamek piastowski w Szczecinie”. Por. C. PISKORski: Zabytki piastowskiego Szczecina. Szczecin 1946; M. RęBkowski: Badania milenijne na Pomorzu Zachodnim. Przebieg, znaczenie, skutki. „Przegląd Archeologiczny” 2017, T. 65, s. 117.

${ }^{23}$ H. SAmsonowicz: Dziedzictwo średniowiecza. Mity i rzeczywistość. Wrocław-Warszawa-Kraków 1991, s. 23. 
nej Mazowsza”, ale ten znamienity władca „nie wykroczył poza partykularny interes swojej dzielnicy". Podział Mazowsza pomiędzy synów został przyrównany przez Kuczyńskiego do stworzenia „polskiej Burgundii”, a na Siemowita spadła odpowiedzialność za pogłębiającą się secesję ziem mazowieckich, regres oraz późniejsze zacofanie tej dzielnicy ${ }^{24}$. Oczywiście w naszych ocenach, szczególnie tych dotyczących późniejszego średniowiecza, pojawiają się władcy źli, którzy realizowali np. tylko interesy dynastyczne, oraz dobrzy, którzy stali po stronie narodowych interesów. Zwykle jednak, głównie w przypadku wcześniejszych wieków średnich, monarcha realizował politykę, w której to, co państwowe, było zbieżne z tym, co narodowe. W ocenie Bolesława Chrobrego Benedykt Zientara oparł się właśnie na takim schemacie myślowym: „[...] musimy stwierdzić, że jego wielka polityka, nie licząca się z możliwościami państwa i jego ludności, przyczyniła się, a nawet spowodowała katastrofę lat trzydziestych XI w. Ale jednocześnie trzeba powiedzieć, że bez szerokich horyzontów i ambicji Bolesława uboższa i mniej dumna byłaby tradycja historyczna, formująca $\mathrm{z}$ wolna oblicze rodzącego się narodu polskiego; uboższe byłyby wzory stawiane przez tę tradycję kolejnym pokoleniom Polaków, od rówieśników Galla Anonima poczynając"25. To klasyczny przykład formułowania ocen ahistorycznych - Chrobry obwiniony został o to, co stało się po jego śmierci, a w zasadzie w 30 lat po rozpoczęciu owej „wielkiej polityki”. Owa polityka sprzeczna była z interesem państwa i narodu — nie liczono się z możliwościami ludności, ale dla przeszłych pokoleń stała się podstawą tradycji narodowej. W ten dość pokrętny sposób Chrobry, oceniony negatywnie przez historyka, wrócił jednak na piedestał wielkich władców jako współtwórca, ale także jeden $\mathrm{z}$ głównych bohaterów tradycji narodowej. Niedaleko odchodzimy w tych opiniach od dziewiętnastowiecznego schematu oceny władcy. Jako wzór tego schematu może posłużyć nam to, co pisał Michał Bobrzyński w swoich Dziejach Polski... Mimo upływu czasu aktualna jest krytyka jego stanowiska dokonana przez Władysława Konopczyńskiego, a mówiąca o nielitościwości „dla wszystkich królów i mężów stanu, co nie przeczuli, czego od nich po trzystu, pięciuset latach zażąda ten lub ów profesor" ${ }^{26}$.

Jako trzecie przekonanie, głęboko zakorzenione w świadomości, wskazać należy tzw. charakter narodowy. To rodzaj odwiecznego przeświadczenia o istnieniu cech charakterologicznych określonych ludów. Osadzone w refleksji egzogennej określić możemy jako stereotypy społeczne czy narodowe. W koncepcji endogennej mamy do czynienia z elementami struktury budującej świadomość grupową, zwykle o charakterze etnicznym. Postrzeganie innych jako

${ }^{24}$ S.K. Kuczyński: Siemowit III Mazowiecki. W: Poczet królów i ksiąząt polskich. Red. A. Garlicki. Warszawa 1984, s. 261.

${ }^{25}$ B. Zientara: Bolesław I Chrobry. W: Poczet królów i książat polskich..., s. 34.

26 W. KonopczyŃski: O wartość naszej spuścizny dziejowej. W: TenżE: Od Sobieskiego do Kościuszki: szkice, drobiazgi, fraszki historyczne. Warszawa 1921, s. 7. 
określonej charakterologicznie, o zdefiniowanych, oczekiwanych zachowaniach, grupy odnosi się także do refleksji nad własnym charakterem narodowym. Filozofia i historiografia XIX stulecia w swej nacjonalnej wizji świata problem charakteru narodowego uczyniły przedmiotem rozważań naukowych. Na gruncie polskim najpełniej tą kwestią zajął się Andrzej Wierzbicki ${ }^{27}$. Refleksja nad cechami charakteru narodowego nie odnosi się do jednej epoki, jest ogólnohistoryczna. W historiografii polskiej doby powojennej najwięcej studiów na ten temat pojawiło się w latach 70. i 80., a zaowocowały one publikacją zbioru Polaków portret własny oraz sesją naukową w Olsztynie w 1984 roku, której pokłosie opublikowano w „Komunikatach Mazursko-Warmińskich”28. Siłą rzeczy w rozważaniach tych zdecydowanie przeważały prace dotyczące epok późniejszych, ale mediewiści wnieśli też swój istotny wkład.

Epoka średniowiecza w refleksjach nad charakterem narodowym ma niebagatelne znaczenie, wskazane przez myślicieli XIX stulecia ${ }^{29}$. Formułując na początku tego wieku zasady badania historii narodowej, zdefiniowano przedmiot badań: „Charakterem narodowym zwiemy przymioty i wady, czyli raczej dobre i złe nałogi, które, jak okrętem kierujące wiatry na obszernej go wieków pochylają przestrzeni i albo na szczyt chwały wynoszą, albo pogrążają w przepaści”, jak czytamy w Odezwie Towarzystwa Królewskiego Przyjaciót Nauk... ${ }^{30}$. Natomiast badanie tego narodowego charakteru sięgać winno przeszłości najdawniejszej, kiedy formował się ów „naród ocierający się z dzikości”, jak pisze jeden z wybitniejszych ówczesnych myślicieli Samuel Benedykt Linde $^{31}$.

Nieprzypadkowo Maria Bogucka we wstępie do trzeciego wydania pracy Dawna Polska... pisze:

Każdy bowiem naród przeżywa swoje dzieje w określonych warunkach obiektywnych, wpływa na ich formowanie, ale i pozostaje w zależności od nich. W wyniku tego wzajemnego oddziaływania rodzi się pewien proces historycznego rozwoju, posiadający własne, odrębne cechy, choć mieszczący się w ramach ogólnych praw. Rozwija się specyficzna kultura i charakter narodowy, rodzą się zalety i przywary, niepowtarzalne w takiej skali wśród innych społeczeństw ${ }^{32}$.

27 A. WierzBicki: Spory o polska duszę. Z zagadnień charakterologii narodowej $w$ historiografii polskiej XIX i XX wieku. Warszawa 2010.

28 Polaków portret wlasny. Red. M. Rostworowski. Kraków 1979; „Komunikaty Mazursko-Warmińskie" 1984, nr 1-2.

${ }^{29}$ M.H. SEREJSKi: Naród i państwo w polskiej myśli historycznej. Warszawa 1977.

${ }^{30}$ Odezwa Towarzystwa Królewskiego Przyjaciół Nauk w sprawie prospektu Historii Narodu Polskiego. W: A. KraushaR: Towarzystwo Królewskie Przyjaciół Nauk 1800-1832. T. 2, cz. 2. Warszawa 1902, s. 220.

${ }^{31}$ AGAD, Warszawskie Królewskie Towarzystwo Przyjaciół Nauk, sygn. 25, Raport do Stanisława Staszica w sprawie prospektu historii narodu Polski, k. 78.

${ }^{32}$ M. Bogucka: Dawna Polska. Narodziny, rozkwit, upadek. Warszawa 1985, s. 5. 
Przekonanie Boguckiej o istnieniu charakteru narodowego idealnie przystaje do definicji tegoż sformułowanej 200 lat temu w Odezwie Towarzystwa Królewskiego Przyjaciół Nauk w sprawie prospektu Historii Narodu Polskiego.

Przeświadczenie o istnieniu charakteru narodowego ujawnić się może w najmniej spodziewanych sytuacjach. W badaniach nad organizacją społeczeństwa i gospodarki w warunkach tworzenia się i funkcjonowania wczesnych monarchii historycy nad wyraz często sięgają po komparatystyczne ustalenie płynące z odwołania do Czech i Węgier. Paralele pomiędzy trzema państwami w tym czasie mają swoje ewidentne podstawy. Jednak sięga się czasami głębiej, wskazując na wielkomorawskie źródła niektórych rozwiązań społeczno-ekonomicznych. Sednem takich działań jest mocno zakorzenione przeświadczenie o istnieniu ducha praw słowiańskich, w XIX stuleciu wyartykułowane przez Wacława Aleksandra Maciejowskiego ${ }^{33}$. Zdecydowanie łatwiej jest bowiem przyjąć pozbawione podstawy źródłowej tezy o wspólnocie prawnej i rozwiązaniach społeczno-ustrojowych sięgających IX wieku, niż dopuścić myśl, że dochodziło do naśladowania rozwiązań płynących $\mathrm{z}$ Niemiec.

Badania historyczne nad charakterem narodowym, najlepiej ujawniającym się w najdawniejszych, średniowiecznych czasach, po II wojnie światowej nabrały nowego znaczenia. Wkraczający do polskiej historiografii marksizm wniósł nowe elementy, wskazywał na potrzebę badania walki klasowej i świadomości społecznej. I tak jak w romantycznej wizji dziejów Polski oraz Słowiańszczyzny podkreślano wartość nieskażonego obcymi naleciałościami charakteru narodowego, tak w niektórych pracach powstałych po 1945 roku najdawniejsza i średniowieczna historia nabrała nowego znaczenia. Na Pierwszej Konferencji Metodologicznej Historyków Polskich w 1953 roku gość z ZSRR, Jewgienij Kosminski (Евгений Алексеевич Косминский), zwracał uwagę na badania nad rolą dziejową Słowian, którym do tej pory burżuazyjna historiografia odmawiała odpowiedniego miejsca w dziejach, dzieląc narody na historyczne i niehistoryczne ${ }^{34}$. Kosminski wzywał: „Czas już wreszcie zerwać

${ }^{33}$ Por. S. Gawlas: O kształt zjednoczonego Królestwa. Niemieckie władztwa terytorialne a geneza społeczno-ustrojowej odrębności Polski. Warszawa 1996, s. 71.

${ }^{34} \mathrm{Na}$ temat konferencji otwockiej powstało już sporo opracowań. Por. R. STOBIECKI: $\mathrm{Hi}$ storiografia PRL. Ani dobra, ani mądra, ani piękna... ale skomplikowana. Warszawa 2007, s. 96-116, tamże zestawienie starszej literatury. O udziale historyków radzieckich pisał Z. Rомек: Historycy radzieccy o historykach polskich. Uwagi o Zjeździe Wrocławskim (1948) i konferencji otwockiej (1951/1952). „Polska 1944/45-1989. Studia i materiały” 1999, T. 4, s. 179-203. W przypadku Jewgienija Kosminskiego mamy do czynienia z dość interesującym przypadkiem swoistego ,powrotu do Polski”. Był on bowiem synem Aleksieja Kosminskiego wieloletniego nauczyciela historii i języka rosyjskiego w warszawskich gimnazjach, potem dyrektora gimazjum. Sam Jewgienij urodził się w Warszawie i znał język polski. To swoiste iunctim $\mathrm{w}$ historii stosunków polsko-rosyjskich — oto syn jednego z wykonawców polityki rusyfikacyjnej caratu w Polsce pojawił się nad Wisłą, aby uczyć polskich historyków właś- 
ostatecznie z tym »europocentryzmem« — zwłaszcza w odniesieniu do historii średniowiecza. Czas już zapewnić właściwe miejsce w historii ludzkości narodom Europy wschodniej, ludom słowiańskim, naddunajskim, Bizancjum, ludom Bliskiego, Środkowego i dalekiego Wschodu" ${ }^{35}$. W odniesieniu do Słowian badacz sygnalizował wysoki poziom kultury rolnej tego ludu — poziom, który pozwolił na bezpośrednie przejście od stadium wspólnoty pierwotnej do feudalizmu, z pominięciem etapu niewolnictwa. Sama kultura Słowian, a także ujawniające się elementy świadomości klasowej i przejawy walki klasowej stały się podstawą budowy nowej wizji charakteru narodowego. Stalinowska koncepcja narodu, w której zwracano uwagę na cechujący go „układ psychiczny", dawała nową podbudowę przekonaniu o istnieniu charakteru narodowego. Swoistym odbiciem tych tez nauki marksistowskiej może być przedstawiony w 1957 roku przez Antoninę Kłoskowską postulat badania „osobowości” klasowo-zawodowych, a nie fikcyjnych typów narodowych ${ }^{36}$. Widoczne w tekstach niektórych polskich mediewistów przeświadczenia o istnieniu charakteru narodowego mają niemożliwe do ustalenia źródła - czy wypływają z dziewiętnastowiecznych korzeni, czy są efektem dyskusji nad „duszą narodową” toczonej w 1. poł. XX wieku, czy mają źródła w adaptowanym na polski grunt marksizmie, nie sposób określić. Bez obaw można jednak wskazać na obecność tej koncepcji czy paradygmatu u wielu badaczy.

Kolejny zespół poglądów ujawniających się w mediewistyce polskiej okresu powojennego nie ma już tak wyrazistego charakteru, jak wcześniej przywołane. To raczej sposób postrzegania najważniejszych ujawniających się w średniowieczu fenomenów, według niektórych badaczy konstytuujących epokę. To swoisty, dziedziczony dzięki naszym przekonaniom obraz epoki. Obraz ten nie jest jednak jednolity. Tak jak niejednolite i pełne różnorodnych zjawisk jest średniowiecze, tak istnieje wiele prób opisu oraz zrozumienia tej epoki przy zastosowaniu jednego klucza. Szczęśliwie nikt w mediewistyce powojennej nie podjął się kontynuacji przedstawiania średniowiecza zgodnie z „mroczną wizją" Józefa Putka. Podobnie rzadko sięga się do romantycznej wizji średniowiecza, stawiającej na takie elementy, jak gotyckość, ludowość, a co najważniejsze - czystość pierwiastków narodowych. Można jednak bardzo często zauważyć wartościowanie zmian zachodzących w przeszłości z pozycji ideowych współczesności. Notoryczne jest stosowanie aksjologii religijnej. W tej ocenie

ciwego podejścia do nauki. Ostatnio wpływ ZSRR na nauki historyczne szeroko przedstawił J. SzumsKi: Polityka a historia. ZSRR wobec nauki historycznej w Polsce w latach 1945-1964. Warszawa 2016.

35 E. Kosminski: Aktualne zagadnienia mediewistyki marksistowsko-leninowskiej. W: Pierwsza Konferencja Metodologiczna Historyków Polskich. Przemówienia - referaty - dyskusja. T. 1. Warszawa 1953, s. 352.

36 A. KŁoskowska: „Charakter narodowy” a osobowość we wspótczesnej problematyce badań społecznych. „Kultura i Społeczeństwo” 1957, T. 1, nr 1, s. 153-154. 
dla chrześcijanina najważniejszym wydarzeniem będzie chrzest Mieszka jako początek Polski chrześcijańskiej (np. prace Oskara Haleckiego). Dla nielicznych, ale występujących z pozycji antychrześcijańskich, to samo wydarzenie oznaczać będzie zanik narodowych pierwiastków pogańskich. Inny rodzaj narracji związany jest z dawnym już sporem o monarchiczne czy republikańskie czynniki warunkujące losy polskiego państwa ${ }^{37}$. Korzenie wielu z tych sposobów postrzegania i narracji o średniowieczu tkwią w dziewiętnastowiecznej historiografii i można tu jedynie zgłosić postulat konieczności podjęcia prac nad tymi problemami.

Konstruując obraz każdej epoki, oprócz przekazu źródeł, historyk odwołuje się do uformowanej wcześniej wizji minionych czasów. To element wiedzy pozaźródłowej, kształtującej naszą świadomą i podświadomą wyobraźnię. W XIX wieku uformowano pewien specyficzny obraz średniowiecza, opierając się przede wszystkim na narodowej wizji świata. Powojenna mediewistyka polska kontynuowała ten sposób opowiadania o przeszłości, czasami jedynie przezwyciężając to dziedzictwo. Do najważniejszych przekonań stanowiących element wypracowanego wówczas paradygmatu należy identyfikacja z przeszłością połączona z przeświadczeniem o odwiecznym istnieniu narodu. Pomimo wielu prac na temat kształtowania się narodu wciąż przeszłość musi być „nasza”. Skrajnym przykładem takiej postawy może być sytuacja w historiografii słowackiej, gdzie ogromna część tekstów poświęcona jest czasom przed pojawieniem się Węgrów, podczas gdy okres X-XI wieku nie cieszy się już takim zainteresowaniem badaczy.

Osadzony w narodowej wizji dziejów paradygmat badawczy zawiera szczególne traktowanie państwa. To losy polityczne wyznaczają wzory konstrukcji narracji, ale też główne elementy podziału polskiego średniowiecza. Klasyczny chronologiczny podział: Polska pierwszych Piastów, czasy rozbicia dzielnicowego, zjednoczenie państwa polskiego, opiera się na wypracowanym w dziewiętnastowiecznej historiografii sposobie rozumienia przeszłości. Tej wizji podporządkowuje się oceny władców, wartościuje się według niej znaczenie faktów i procesów.

Stefan Kwiatkowski w swych rozważaniach nad polską mediewistyką ,,czasów maszynopisu" zwrócił uwagę na różnice pomiędzy polską historiografią a nauką anglosaską, niemiecką i francuską. Według niego tam zmierza się do odpowiedzi na kwestie teoriopoznawcze podnoszone we współczesnych nurtach intelektualnych, podczas gdy nasza historiografia, w tym mediewistyka, tworzy wiedzę pewną, stałą i niezmienną ${ }^{38}$. Czyż nie jest to efekt osadzenia naszego rozumienia przeszłości w przekonaniach „olbrzymów” dziewiętnastowiecznej historiografii?

\footnotetext{
37 J. Adamus: Monarchizm i republikanizm w syntezie dziejów Polski. Łódź 1961.

38 S. Kwiatkowski: Polska mediewistyka..., s. 169.
} 


\section{Bibliografia}

\section{Źródla rękopiśmienne}

Archiwum Główne Akt Dawnych, Warszawskie Królewskie Towarzystwo Przyjaciół Nauk, sygn. 25, Raport do Stanisława Staszica w sprawie prospektu historii narodu Polski.

\section{Źródla drukowane}

Odezwa Towarzystwa Królewskiego Przyjaciót Nauk w sprawie prospektu Historii Narodu Polskiego. W: A. Kraushar: Towarzystwo Królewskie Przyjaciót Nauk 1800—1832. T. 2, cz. 2. Warszawa 1902.

\section{Opracowania}

Achremczyк S.: Historia Warmii i Mazur: od pradziejów do 1945 roku. Olsztyn 1992.

Adamus J.: Monarchizm i republikanizm w syntezie dziejów Polski. Łódź 1961.

Bogdanowicz P.: Przynależność polityczna Ślaska w X wieku. Dzieje problemu oraz próba jego rozwiazania. Wrocław 1968.

Bogucka M.: Dawna Polska. Narodziny, rozkwit, upadek. Warszawa 1985.

BogusŁawski W.: Dzieje Stowiańszczyzny pótnocno-zachodniej. Poznań 2005.

Boroń P.: Stowianie - my i nasi przodkowie. Etyczne aspekty poszukiwania pradawnej chwaty ludów słowiańskich w pracach historyków polskich I połowy XIX wieku. W: Narracje(auto)biografia - etyka. Red. L. Koczanowicz, R. Nahirny, R. WeodarczyK. Wrocław 2005.

CETwIŃski M.: Historia i polityka. Teoria i praktyka mediewistyki na przykładzie badań dziejów Śląska. Kraków 2008.

Dzieje Warmii i Mazur w zarysie. T. 1. Red. J. Sikorski, S. Szostakowski. Warszawa 1981; T. 2. Red. T. Filipkowski [et al.]. Warszawa 1983.

Gawlas S.: O ksztalt zjednoczonego Królestwa. Niemieckie władztwa terytorialne a geneza społeczno-ustrojowej odrębności Polski. Warszawa 1996.

GRZESIK R., rec.: Slavnikovci ve středovékém písemnictví úvodni studii..., ed. Rastislav Nový, Praha 1987. „Kwartalnik Historyczny” 1991, T. 98, z. 1.

IwaŃcZaK W.: Między Europa i Azją. Sąsiedzi Polski w świetle mediewistyki XX wieku. W: Mediewistyka polska w XX wieku (wybrane problemy). Red. S. KwiatKowsKi. Wrocław 2008.

JEŻ T.T.: Historia o pra-pra-pra... wnuku i pra-pra-pra... dziadku. Cz. 1. Wilno 1863. 
KŁoskowska A.: „Charakter narodowy” a osobowość we współczesnej problematyce badań społecznych. „Kultura i Społeczeństwo” 1957, T. 1, nr 1.

KONOPCZYŃSKI W.: O wartość naszej spuścizny dziejowej. W: W. KonOPCZYŃsKI: Od Sobieskiego do Kościuszki: szkice, drobiazgi, fraszki historyczne. Warszawa 1921.

Kosminski E.: Aktualne zagadnienia mediewistyki marksistowsko-leninowskiej. W: Pierwsza Konferencja Metodologiczna Historyków Polskich. Przemówienia - referaty - dyskusja. T. 1. Warszawa 1953.

Kostrzewski J.: Kultura prapolska. Poznań 1949.

KucZyŃski S.K.: Siemowit III Mazowiecki. W: Poczet królów i książat polskich. Red. A. GaRLICKI. Warszawa 1984.

Kunn T.: The Structure of Scientific Revolutions. Chicago 1962.

KwiatKowski S.: Polska mediewistyka historyczna w czasach maszynopisu. O wymuszonej modernizacji i okolicznościach jej przemijania. Poznań 2010.

Lewicki A.: Zarys historyi Polski i krajów ruskich z nia połaczonych. Kraków 1884.

Maciejowski W.A.: Pierwotne dzieje Polski i Litwy. Poznań 2005.

Mediewistyka polska w XX wieku (wybrane problemy). Red. S. KwiatKowsKi. Wrocław 2008.

NalePa J.: Prapolski bastion toponimiczny w Bramie Przemyskiej i Lędzanie. „Onomastica” 1991, T. 36.

Norwid C.K.: Przeszłość. W: C.K. Norwid: Poezje. Poznań 1986.

Piskorski C.: Zabytki piastowskiego Szczecina. Szczecin 1946.

Polaków portret własny. Red. M. RosTworowsKi. Kraków 1979.

PopioŁek K.: Historia Śląska od pradziejów do 1945 roku. Katowice 1984.

RęBкowski M.: Badania milenijne na Pomorzu Zachodnim. Przebieg, znaczenie, skutki. „Przegląd Archeologiczny" 2017, T. 65.

RoePell R.: Dzieje Polski do XIV stulecia. Poznań 2005.

RoMeK Z.: Historycy radzieccy o historykach polskich. Uwagi o Zjeździe Wrocławskim (1948) $i$ konferencji otwockiej (1951/1952). „Polska 1944/45-1989. Studia i materiały” 1999, T. 4.

Samsonowicz H.: Dziedzictwo średniowiecza. Mity i rzeczywistość. Wrocław-WarszawaKraków 1991.

SeRejSKi M.H.: Naród i państwo w polskiej myśli historycznej. Warszawa 1977.

Stobiecki R.: Historiografia PRL. Ani dobra, ani madra, ani piękna... ale skomplikowana. Warszawa 2007.

Szafarzyk P.J.: Stowiańskie starożytności. Poznań 2003.

SzAfraŃSKi W.: Tadeusz Wieczorowski. „Z Otchłani Wieków” 1971, T. 37, z. 1.

Szczur S.: Historia Polski. Średniowiecze. Warszawa 2002.

SzUMSKi J.: Polityka a historia. ZSRR wobec nauki historycznej w Polsce w latach 1945-1964. Warszawa 2016.

ŚRENIOwSKA K.: Stanisław Zakrzewski: przyczynek do charakterystyki prąów ideologicznych w historiografii polskiej 1893-1936. Łódź 1956.

Topolski J.: Gtówne tendencje rozwojowe historiografii XIX i XX wieku. „Kwartalnik Historyczny" 1983, T. 90.

TOPOLSK J.: Jak się pisze i rozumie historię. Tajemnice narracji historycznej. Poznań 2008.

TřEŠTík D.: Powstanie Wielkich Moraw. Morawianie, Czesi i Europa Środkowa w latach 791871. Przeł. E.H. KaczmarsKa. Warszawa 2009.

Wierzbicka M.: Dawne syntezy dziejów Polski. Rozwój i przemiany koncepcji metodologicznych. Wrocław-Warszawa-Kraków-Gdańsk 1974.

WIERZBICKI A.: Spory o polska duszę. Z zagadnień charakterologii narodowej w historiografii polskiej XIX i XX wieku. Warszawa 2010. 
Zakrzewski S.: Okres do schyłku XII w. W: Historya polityczna Polski. Cz. 1: Wieki średnie. Oprac. S. ZaKrZEWSKI et al. Kraków 1920.

Zientara B.: Bolestaw I Chrobry. W: Poczet królów i książą polskich. Red. A. Garlicki. Warszawa 1984.

\section{Piotr Boroń}

The post-war Polish medieval studies in relation to the nineteenth-century historiography

Summary

The article presents reflection on the presence of the nineteenth-century convictions and visions of the past in the Polish post-war medieval studies practiced on the historical ground. The nineteenth century was the time when modern critical historiography started to be created. For practical reasons the article discusses only the field of history, without referring to other fields that also practice medieval studies. The author emphasizes numerous historiographic references to the nineteenth-century paradigms of perceiving the past. One of them was the paradigm of describing the "national" past. What is also signaled in this study are rather archaic manners of describing the past in the post-war period and the utilitarian character of some historical studies.

Keywords: medieval studies, historiography, nineteenth-century historical thought, post-war Polish historiography, historiography in communist Poland

\section{Piotr Boroń}

\section{Die polnische Nachkriegsmediävistik über das Erbe des historischen Denkens im neunzehnten Jahrhundert}

\section{Zusammenfassung}

Der Artikel beschäftigt sich mit den in der polnischen Nachkriegsmediävistik (nach 1945) vorhandenen Ansichten und Vorstellungen über die Vergangenheit, die noch im neunzehnten Jahrhundert verankert waren, als sich die moderne, kritische Geschichtsschreibung erst zu entwickeln begann. Aus praktischen Gründen betrifft die Skizze nur die historische Mediävistik, ohne sich auf andere Wissenschaften vom Mittelalter zu beziehen. Der Autor macht auf zahlreiche historiographische Bezüge auf die aus dem neunzehnten Jahrhundert stammenden Paradigmen über die Wahrnehmung der Vergangenheit aufmerksam. Eines der Paradigmen war die Betrachtung der Vergangenheit von einem „nationalen“ Standpunkt aus. Darüber hinaus wurde auf die Anwendung von ziemlich archaischen Methoden der Vergangenheitsbeschreibung in der Nachkriegszeit sowie auf einen utilitären Charakter mancher historischen Arbeiten hingewiesen.

Schlüsselwörter: Mediävistik, Geschichtsschreibung, historisches Denken im 19. Jahrhundert, polnische Geschichtsschreibung nach 1945, Geschichtsschreibung in der Volksrepublik Polen 